\title{
FUNCTIONAL IMPROVEMENT UP TO SIX MONTHS AFTER TOTAL HIP ARTHROPLASTY: MEASURED BY SELF-REPORTED QUESTIONNAIRE AND RANGE OF HIP FLEXION
}

\author{
Mirjana Kocić1,2, Marina Milenkovićs, Marija Spalević ${ }^{1}$, Aleksandra Krstović1, \\ Anita Stanković ${ }^{1}$, Dragan Zlatanović1,2
}

\begin{abstract}
The aim of this study was to assess patients' self-reported hip function, as well as hip flexion and flexion contracture preoperatively, three and six months after total hip arthroplasty (THA). The secondary aim was to analyze the extent to which postoperative patients' selfreported hip function three and six months after THA correlates with preoperative patients' selfreported function, hip flexion and flexion contracture.

A longitudinal cohort study included 100 patients with the end stage of hip osteoarthritis who underwent THA at the Orthopedic Clinic from May 2015 to November 2016. The patients were assessed at three time points: preoperatively and at 3 and 6 months after THA. First, hip flexion and flexion contracture were measured. Then the patients completed the selfreported questionnaire for evaluation of hip function-Oxford hip score.

The results showed poor self-reported hip function, hip flexion and flexion contracture preoperatively. At 3 months follow-up, as well as at 6 months follow-up, self-reported hip function and flexion were significantly increased $(p<0.001)$ and hip flexion contracture was significantly decreased $(p<0.001$ ) in relation to preoperative values. According to values of Spearman correlation coefficient, significant correlations were found between self-reported hip function at 3 months follow-up and preoperative function, hip flexion and flexion contracture, but all correlations disappeared by 6-month follow-up. The study indicates that poor preoperative hip function and hip flexion may slow down functional recovery after TAK, but do not compromise the outcome 6 months after THA.
\end{abstract}

Acta Medica Medianae 2020;59(2):20-27.

Key words: Total hip arthroplasty, self-reported functional outcome, hip flexion, hip flexion contracture

\footnotetext{
${ }^{1}$ Physical Medicine and Rehabilitation Clinic, Clinical Center Niš, Serbia

${ }^{2}$ University of Niš, Faculty of Medicine, Niš, Serbia

${ }^{3}$ National Health Insurance Fund, Niš, Serbia
}

Contact: Mirjana Kocić

48 Dr.Zoran Djindjić Blvd., 18000 Niš, Serbia

E-mail: kocicm60@gmail.com

\section{Introduction}

Total hip arthroplasty (THA) is a successful surgical treatment for people with end-stage hip osteoarthritis, when conservative treatment is no longer effective (1-4). It provides significant pain relief and improvement in function to a painful, degeneratively altered and reduced in motion hip joint (4-6). THA is considered to be the operation of the twentieth century, as it has become a turning point in the treatment of elderly people suffering from degenerative hip joint disease, with very good long-term results (7). It has been applied for more than half a century and has been constantly improved during this period. The number of the operations has been steadily increasing over the past decades, and in future decades an exponential rise in the number of both primary and revision THA is expected, because of the ageing population (8). Thanks to the advancement in implant technology, surgical techniques and anesthesia indications for the THA are significantly expanded but the most common indication for THA is still primary degenerative hip joint disease (9). These operations are now performed in younger, more active people who would not have been candidates for THA in the previous period (10). Most patients after THA achieve a satisfactory functional recovery however, in a minority of patients functional limitations remain $(4,8)$.

The assessment of outcomes after THA can be done in several ways. In the first decades after the introduction of THA, the outcome was evaluated by the orthopedic surgeon on the basis of implant 
survival rates, implant-related complications, radiographic positions of endoprosthetic components, range of hip motion etc. $(5,11,12)$. Later, several numerical scores were introduced to quantify the outcome of arthroplasty, which made comparison of the outcomes possible. Among the most commonly used numerical scores was the Harris's hip score (HHS), where assessment of pain and function, as well as measurement of the range of the hip motion and the presence of hip contracture were done by a surgeon (13).

On evaluating the outcomes, it appeared that patients are less satisfied than surgeons $(6,12,14)$. Because of the discrepancy between the points of view of patients and clinicians in the past decades, the evaluation of outcome after arthroplasty has been shifted to the use of patient reported outcome measures (PROMs) so as to see whether arthroplasty is successful from the patient's perspective (2, $4,8,11,12,15)$. To evaluate hip arthroplasty outcomes, several PROMs instruments have been developed containing questions related to pain and functional activities specific for the hip joint. Among the most commonly used PROMs after THA is the Oxford hip score (OHS) (16). The OHS was designed to evaluate the functional ability of patients with THA (16). The OHS has been used since its introduction in 1996, and has proven reliability and validity (5). Furthermore, the OHS is strongly correlated with the HHS before and after hip surgery (5). The OHS and HHS have some similar items regarding pain and function evaluation, but the OHS does not include measuring of hip range of motion and flexion contracture (6).

We were interested in investigating the improvement of the hip function up to 6 months after THA, both from the perspective of the patient and on the basis of objective parameters, such as the range of hip flexion and flexion contracture.

\section{Aim}

Therefore, the primary aim of this study was to assess patients' self-reported function as well as range of active hip flexion and hip flexion contracture preoperatively and three and six months after THA. The secondary aim was to analyze the extent to which postoperative patients' self-reported hip function three and six months after THA correlates with preoperative patients' self-reported function, range of hip flexion and flexion contracture.

\section{Patients and methods}

A longitudinal cohort study recruited 122 patients with the end stage of hip osteoarthritis admitted at the Orthopedic Clinic, Clinical Center Niš, from May 2015 to November 2016 to undergo THA. All the patients received post-acute inpatient rehabilitation at the Physical Medicine and Rehabilitation Clinic starting a few days after THA. The inclusion criteria for the study were: primary unilateral THA for $O A$ and willingness to participate in the study. The exclusion criteria were: cognitive impairment
(Mini-Mental State Examination score < 24) (17), revision THA or the previous lower limb surgery, severe chronic diseases that limit physical functioning. After applying the inclusion and exclusion criteria, 100 patients were eligible for the study and written informed consents were obtained.

The sociodemographic and health data that included age, sex, BMI value, duration of the disease symptoms, as well as comorbidity were collected preoperatively through face-to-face interviews and from medical records. The patients' body height and weight measures were taken, and body mass index (BMI) was calculated and recorded in $\mathrm{kg} / \mathrm{m}^{2}$. Comorbidity was assessed by the Charlson Comorbidity Index (CCI). It includes 19 conditions, each of which was assigned - 1, 2, 3 or 6 points. CCI was expressed as a summative score range from 0 to 33, with higher score indicating the higher comorbidity burden (18).

\section{Assessments}

The patients were assessed at three time points: preoperatively (24-48 hours before the surgery) and at 3 and 6 months after the surgery. First, hip flexion range and flexion contracture were measured. Then the patients filled in the self-reported questionnaire for evaluation of hip function - OHS.

\section{Self-reported function}

The self- reported function of hip joint was estimated using the OHS, which is designed and validated as a self-reported joint-specific questionnaire for evaluation of the outcomes of THA. The OHS consists of 12 questions which refer to hip pain and function during the last 4 weeks. Each question is in the Likert scale valued from 0 to 4 . An overall score is created by summing the responses to each of the 12 questions. The total score can range from 0 to 48 , where the higher score represents the better function $(16,19)$.

\section{Active hip flexion and flexion contracture}

The range of active hip flexion was measured in degrees using a long-arm, full-circle handheld goniometer. The patient was placed in a supine position on an examination table with hips at neutral and knees in extension. The goniometer was centered on hip joint. Then the patient moved the hip to the maximum flexion and the degree of flexion was measured and recorded. While returning to the starting position of the full extension, the limited motion was measured and expressed as hip flexion contracture. The range of active hip flexion was measured and recorded in degrees according to the method suggested by the American Academy of Orthopedic Surgeons (20). The same investigator with more than ten years of experience measured ROM twice at all assessment time points with the same goniometer (made of flexible clear plastic) and the mean value was recorded. 


\section{Statistical analysis}

The continuous variables were described by means \pm standard deviations and by medians. For the categorical variables, absolute numbers and percentages were given. The distributions of the continuous variables were assessed for normality by Kolmogorov-Smirnov test. The differences between independent groups were analyzed by an unpaired ttest in case of a normal distribution or by MannWhitney U-Test if the distribution of data was not normal. A chi-square test was used to compare proportions of categorical variables between groups. To compare cases of two related observations a Wilcoxon Signed-Ranks was used because the distribution of data was not normal. To analyze associations between continuous variables Spearman ( $r$ ) correlation coefficient was used. $P$ values less than 0.05 were considered significant. The calculations were carried out using the SPSS statistical package version 15.0 .

\section{Results}

Baseline characteristics of patients
The study included 100 patients with endstage hip osteoarthritis immediately prior to THA. The mean age of study patients at baseline was 64.1 \pm 8.7 years and $55 \%$ were female. The average duration of symptomatic osteoarthritis in our patients was $5.9 \pm 3.9$ years and according to the WHO classification they were overweight with the mean BMI of $27.5 \pm 3.9$. Because of the role of comorbidity in recovery patients with THA, we calculated CCI and the mean was $0.5 \pm 0.8$. Regarding examined parameters before surgery: the mean OHS was $13.9 \pm 5.5$, the mean hip flexion was 66.0 \pm 18.7 degrees and the mean hip flexion contracture was $6.2 \pm 4.9$.

Out of 100 patients who started the study, $92 \%$ attended the 3-month postoperative follow-up and this declined to an $81 \%$ attendance rate by the 6-month follow-up. The comparison of the baseline characteristics of the patients that completed the study and did not attend to the 6-month follow-up is presented in Table 1.

No significant differences were found in any of the baseline characteristics between the patients who completed the study and those who dropped out from the study (Table 1 ).

Table 1. Baseline characteristics of patients who completed the study versus patients who dropped out

\begin{tabular}{|c|c|c|c|c|c|}
\hline \multirow[b]{2}{*}{ Characteristics of patients } & \multicolumn{5}{|c|}{ Patients $(n=100)$} \\
\hline & \multicolumn{2}{|c|}{$\begin{array}{l}\text { Completed the } \\
\text { study }(n=81)\end{array}$} & \multicolumn{2}{|c|}{$\begin{array}{c}\text { Dropped out of the } \\
\text { study }(n=19)\end{array}$} & $P$ \\
\hline Age (years) & \multicolumn{2}{|c|}{$\begin{array}{c}64.02 \pm 8.73 \\
(65.00) \\
\end{array}$} & \multicolumn{2}{|r|}{$\begin{array}{c}64.53 \pm 8.57 \\
(64.00) \\
\end{array}$} & 0.8216 \\
\hline \multicolumn{6}{|l|}{ Gender } \\
\hline Male & 37 & $45.68 \%$ & 8 & $42.11 \%$ & 0.7792 \\
\hline Female & 44 & $54.32 \%$ & 11 & $57.89 \%$ & \\
\hline BMI $\left(\mathrm{kg} / \mathrm{m}^{2}\right)$ & \multicolumn{2}{|c|}{$\begin{array}{c}27.17 \pm 3.77 \\
(26.70)\end{array}$} & \multicolumn{2}{|r|}{$\begin{array}{c}28.89 \pm 4.28 \\
(28.10)\end{array}$} & 0.0976 \\
\hline Symptoms duration (years) & \multicolumn{2}{|c|}{$\begin{array}{c}5.56 \pm 3.51 \\
(5.00)\end{array}$} & \multicolumn{2}{|r|}{$\begin{array}{c}7.16 \pm 5.28 \\
(6.00)\end{array}$} & 0.1208 \\
\hline CCI (0-33 score) & \multicolumn{2}{|c|}{$\begin{array}{c}0.58 \pm 0.86 \\
(0.00)\end{array}$} & \multicolumn{2}{|r|}{$\begin{array}{c}0.21 \pm 0.42 \\
(0.00)\end{array}$} & 0.1136 \\
\hline Hip flexion (degrees) & \multicolumn{2}{|c|}{$\begin{array}{c}65.19 \pm 18.58 \\
(70.00)\end{array}$} & \multicolumn{2}{|r|}{$\begin{array}{c}69.47 \pm 19.14 \\
(70.00)\end{array}$} & 0.4708 \\
\hline Hip flexion contracture (degrees) & \multicolumn{2}{|c|}{$\begin{array}{c}5.99 \pm 4.36 \\
(5.00)\end{array}$} & \multicolumn{2}{|r|}{$\begin{array}{c}6.84 \pm 6.71 \\
(5.00)\end{array}$} & 0.9533 \\
\hline OHS (0-48 score) & \multicolumn{2}{|c|}{$\begin{array}{c}14.06 \pm 5.54 \\
(13.00)\end{array}$} & \multicolumn{2}{|r|}{$\begin{array}{c}13.42 \pm 5.23 \\
(14.00)\end{array}$} & 0.8121 \\
\hline
\end{tabular}

Continues variables are given as means \pm SD (medians); categorical variables are given as frequencies (percentages); BMI, Body mass index; CCI Charlson Comorbidity Index (higher score indicating the higher comorbidity burden); ROM, range of motion; OHS, Oxford hip score (higher score representing the better function) 
THA

Examined parameters up to six months after

Table 2 shows the values of the examined parameters before surgery, at 3 and 6 months postoperatively, for the patients who participated in the whole of the study. At 3 months, as well as at 6 months postoperatively in our cohort of patients all the three examined parameters significantly improved in relation to preoperative values at the highest level of significance $(p<0.001)$. Self-reported function had significantly increased from 14.06 (SD
5.54) preoperatively to 31.91 (SD 3.84) at 3 months after surgery $(p<0.001)$ and to 42.15 (SD 3.87) at 6 months after surgery $(p<0.001)$. The range of hip flexion movement had significantly increased from 65.19 (SD 18.58) preoperatively to 80.62 (SD $9.66)$ at 3 months after surgery $(p<0.001)$ and to 93.58 (SD7.76) at 6 months after surgery ( $p<$ $0.001)$. The mean degree of hip flexion contracture was significantly decreased from 5.99 (SD 4.36) preoperatively to 2.78 (SD 3.45) at 3 months after surgery $(p<0.001)$ and to 1.91 (SD 2.91) at 6 months after surgery $(p<0.001)$ (Table 2$)$.

Table 2. Examined parametres preoperatively, at 3 and 6 months follow-up for THA patients who completed the study

\begin{tabular}{|c||c|c|c|}
\hline \multicolumn{1}{|c||}{$\begin{array}{c}\text { Examined } \\
\text { parametres }\end{array}$} & \multicolumn{3}{|c|}{ Assessment time } \\
\hline \hline \multirow{2}{*}{ OHS } & Preoperatively & $\begin{array}{c}3 \text { months follow-up } \\
(\mathrm{n}=92)\end{array}$ & $\begin{array}{c}6 \text { months follow-up } \\
(\mathrm{n}=81)\end{array}$ \\
\hline \multirow{2}{*}{$\begin{array}{c}14.06 \pm 5.54 \\
(13.00)\end{array}$} & $\begin{array}{c}31.91 \pm 3.84 \\
(32.00)^{* * *}\end{array}$ & $\begin{array}{c}42.15 \pm 3.87 \\
(43.00)^{* * *}\end{array}$ \\
\hline $\begin{array}{c}\text { Hip flexion } \\
\text { (degrees) }\end{array}$ & $\begin{array}{c}6.19 \pm 18.58 \\
(70.00)\end{array}$ & $\begin{array}{c}80.62 \pm 9.66 \\
(80.00)^{* * *}\end{array}$ & $\begin{array}{c}93.58 \pm 7.76 \\
(95.00)^{* * *}\end{array}$ \\
\hline $\begin{array}{c}\text { Hip flexion } \\
\text { contracture } \\
\text { (degrees) }\end{array}$ & $\begin{array}{c}5.99 \pm 4.36 \\
(5.00)\end{array}$ & $\begin{array}{c}2.78 \pm 3.45 \\
(0.00)^{* * *}\end{array}$ & $\begin{array}{c}1.91 \pm 2.91 \\
(0.00)^{* * *}\end{array}$ \\
\hline
\end{tabular}

Continues variables are given as means \pm SD (medians); OHS, Oxford hip score (higher score representing the better function); Wilcoxon Signed-Ranks (* $-p<0.05, * *-p<0.01, * * *-p<0.001)$

Correlation between examined preoperative parametres and post-operative OHS

The correlation between the examined preoperative parametres and the post-operative OHS is shown in Table 3. The significant correlations were found be-tween the 3 months post-operative OHS and all the examined preoperative parameters. There was a po-sitive correlation with the preopera- tive OHS (Spearman's $r=0.30 ; P=0.0038$ ) and the preoperative hip flexion (Spearman's $r=0.27$; $P$ $=0.0095)$, but a negative correlation with the preoperative hip flexion contracture (Spearman's $r=$ $-025 ; P=0.0146$ ). No significant correlation of the 6 months post-operative OHS value with any of the examined preoperative parameters was found (Table 3).

Table 3. Correlation between preoperative OHS, hip flexion and flexion contracture with postoperative OHS

\begin{tabular}{|c||c|c|c||c|c|c||}
\hline \hline \multicolumn{1}{|c||}{$\begin{array}{c}\text { Examined parametres } \\
\text { preoperatively }\end{array}$} & \multicolumn{3}{|c||}{$\begin{array}{c}\text { OHS } \\
3 \text { months follow-up }\end{array}$} & \multicolumn{4}{|c|}{$\begin{array}{c}\text { OHS } \\
\text { months follow-up }\end{array}$} \\
\hline \hline OHS & 0.30 & $(0.0038)$ & $* * *$ & 0.19 & $(0.0894)$ & \\
\hline Hip flexion & 0.27 & $(0.0095)$ & $* *$ & 0.11 & $(0.3458)$ & \\
\hline Hip flexion contracture & -0.25 & $(0.0146)$ & $*$ & -0.15 & $(0.1841)$ & \\
\hline
\end{tabular}

OHS, Oxford hip score; Spearman's (* $-\mathrm{p}<0.05, * *-p<0.01, * * *-p<0.001)$ 


\section{Discussion}

Our results showed significant improvement of all the three examined parameters (self-rated hip function, hip flexion and flexion contracture) at the follow-up 3 and 6 months after THA in comparison to their preoperative values.

In order to evaluate hip function from the patients' perspective in the present study the OHS was used as a PROMs instrument $(16,19)$. The mean preoperative OHS was very low with the value of 14 points which represents a very poor hip function according to Kalairajah et al. (21). In contrast to our findings, as well as in other studies, the preoperative OHS was higher than in our study with the range between 16.4 and 19.7 (3, 4, 8, 11, 12, 15).

As expected, at 3 and 6-month check-ups after THA, we found statistically significant improvement of OHS ( $p<0,001)$. Three months post-operatively the mean OHS value was approximately 32 points, and six months post-operatively it was approximately 42 points. According to Kalairajah et al., the achieved OHS value of 42 points after six months is considered as an excellent outcome (21). Also, such OHS value indicates the satisfactory hip function according to Judge et al. whose study shows that the threshold for OHS for high satisfaction 6 months following THA was 35 points (15). Our findings are consistent with other authors' findings who also found significant improvement of OHS 3 and 6 months after THA as compared to preoperative values $(5,11,12)$. In the study of Heiberg et al. that included 1523 patients with primary THA who completed the six-month post-operative OHS Questionnaire, the mean OHS was 38.8 (15) which was almost identical to the mean OHS of 39 points found by Kjærgaard et al. in 100 patients 6 months after THA (11). Other studies that examined patients up to 12 months after THA found substantial OHS improvement 12 months after THA as compared to the preoperative values $(3,4,5,6,8)$ while some authors used another OHS scale consisting of 12-60 points, with minimum score of 12 points representing the best hip function $(5,6)$. Based on the evaluation data from a regional joint arthroplasty registry for 3203 THA patients, Hamilton et al. found that the mean OHS 12 months post-operatively was 38.6 (3). In 619 patients, Arden et al. found the mean OHS higher with the value of 43 points on an average 12 months after THA (8). The identical OHS of 43 points one year after surgery was shown by the multicentric study conducted in seven hospitals across England and Scotland, which included 1375 patients with 1431 primary THA for osteoarthritis. This study followed the patients 5 years after THA and demonstrated that the mean value of OHS did not change between 1 year after surgery and 5 years after surgery (4).

In 2016, in the systematic review, Hofstede et al. showed that although patients with worse preoperative function had a greater improvement, they did not achieve the postoperative level of those with higher preoperative function (1). In contrast to their findings, in our study, the patients had poor preoperative score, but 6 months after THA they 24 achieved excellent hip function. In the present study, the same or even slightly better than in other studies, postoperative OHS 3 and 6 months after surgery can be attributed to the fact that all the patients in our study after the acute rehabilitation at the Orthopedic Clinic received 21 days long postacute rehabilitation at the Physical medicine and rehabilitation Clinic.

The hip range of motion, in evaluation of the outcomes after THA, has a disputable value (22). In his score for hip function evaluation (HHS), Harris assigned only 5 out of total of 100 points to the overall hip range of motion, considering that what is necessary for hip function is relatively low range of motion in comparison to what is available by the anatomy configuration of a normal hip joint (13). As opposed to Harris, Davis et al., showed that the range of hip motion is more significant than what was considered before. They analyzed the range of hip motion in 1383 patients (1517 hips) with primary THA and determined that postoperative range of hip motion is in strong correlation with hip the function in the sense that the higher the range of motion the better is the hip function (22). The required range of hip motion for different activities of daily life varies considerably. Walking on a flat surface, as the most common DLA, does not require high hip flexion movement. Some daily life activities, such as tying the shoes, catching items from the floor and moving from standing to sitting, require high hip flexion movement (minimum $95^{\circ} \mathrm{C}$ )(23).

For the evaluation of outcomes after THA, we used active hip range of flexion and degree of flexion contracture of hip. We decided to measure only the range of hip flexion, not the total range of hip movement, because it has been proved that the range of hip flexion correlates strongly with the total range of movement in all three planes (24). In the present study, it was found that the preoperative average active hip flexion was 65 degrees and the hip flexion rate 6 degrees. The mean preoperative hip flexion in our study was lower than in studies of other authors $(2,5)$, where the mean preoperative flexion was 81 degree. Our patients had a preoperatively higher degree of hip flexion contracture compared to Heiberg et al. (2). A possible explanation for an average lower preoperative OHS, a lower degree of hip flexion and a higher degree of flexion contracture in our study may be that in Serbia patients usually postpone surgery, and functional parameters are disturbed in a higher degree.

In the present study, a statistically significant increase in hip flexion was found 3 months after the THA when the average flexion was approximately 81 degrees, and 6 months after THA when the average F was approximately 94 degrees. Also, a statistically significant reduction in hip flexion was found to be $2.78 \pm 3.453$ months after the THA, and 6 months after the THA it was $1.91 \pm 2.91$. Increasing the range of movement is important because it is associated with a better hip function (22). Reduction of flexion contraction is also significant because the hip flexion contracture after THA causes pain in the hip joint and lower part of the back and walking disorders (25). Other authors found a higher hip flexion than we did in our study 3 months after surgery (2, 
5). Explanation for a lower range of movement 3 months after surgery in our patients can be found in the lower degree of preoperative hip flexion. Röder et al. in a retrospective study that included data from approximately $13,000 \mathrm{THA}$, found that a lower preoperative hip movement also led to a minor improvement in mobility after THA (26). However, at the control examination, six months after surgery, our patients achieved a relatively satisfactory hip flexion of an average of 94 degrees, which is found approximately similar to findings of other authors (2, 5). In the study of Kawai et al. which involved 120 patients with a primary THA, the mean hip flexion was 91.9 at 3 months post-THA, and 92.6 at 6 months post-THA (5). In the study of Heiberg et al. which included 88 patients with a primary THA, the mean hip flexion 3 months after surgery was 84 , and 12 months after surgery 94 degrees. A statistically significant increase in hip flexion compared to preoperative values was achieved at the 12-month follow-up after surgery (2). They had a 6-week exercise program starting 3 months postoperatively (which can be taken as an explanation for the significant improvement shown 3 months after THA). It is important to note that comparisons of hip flexion are often difficult to perform, since in many studies, the way in which the hip flexion is measured is not precisely explained (in which position the patient was initially set and whether it is an active or passive range of movement).

Regarding the correlation of postoperative self-reported function 3 months after surgery and the examined preoperative parameters, a positive correlation was found with preoperative function ( $p$ $<0.01$ ) and hip flexion ( $p<0.01)$, and negative correlation with hip flexion contracture $(p<0.05)$. However, 6 months after THA, no correlation of postoperative function was found with any of the examined preoperative parameters. It shows that the lower preoperative OHS values and lower hip flexion and higher degree of hip flexion contraction are in correlation with the lower level of self reported hip function 3 months after THA, but not in correlation with the hip function 6 months after surgery, thus they are not expected to be correlated with the function 6 months after surgery. The results obtained could indicate that patients with better preoperative parameters recover faster after surgery. It does not mean that the patients with worse preoperative parameters are not good candidates for THA, but the recovery in such patients requires longer period of time. Our findings are partly in accordance with findings of some other authors. Several studies have found, like our study, a correlation of the postoperative function with a preoperative function 3 months after surgery $(4,5)$, but in contrast to our study, in these studies a correlation of the preoperative function and postoperative function was found not only after 3 but also after 6 and 12 months $(4,5)$. In contrast to the present study, Kawai et al. did not find a correlation between preoperative flexion and the postoperative self-reported function either 3 , or 6 , or 12 months after THA (5). Further longitudinal studies with larger sample size are required in order to provide more information about the correlation of poor preoperative function and hip range of motion, and postoperative functional outcomes.

\section{Conclusion}

We found poor self-reported hip function, hip flexion and flexion contracture immediately before THA. Our results showed significant improvement of all the three examined parameters (self-rated function, hip flexion and hip flexion contracture) from the preoperative values to the control values at 3 , as well as at 6 month check-up after THA. A positive correlation was found between self-reported function 3 months after THA with preoperative function ( $p<$ $0.01)$ and hip flexion $(p<0.01)$, as well as a negative correlation with hip flexion contracture $(p<$ 0.05 ), but all correlations disappeared within 6 months postoperatively (for all the parameters). The study indicates that in a cohort of patients undergoing THA, operating on patients with poor hip function, low degree of range of hip flexion and high degree of hip flexion contracture may slow down functional recovery, but not compromise the outcome 6 months after THA. 


\section{References}

1. Hofstede SN, Gademan MG, Vliet Vlieland TP, Nelissen RG, Marang-van de Mheen PJ. Preoperative predictors for outcomes after total hip replacement in patients with osteoarthritis: a systematic review. BMC Musculoskelet Disord 2016;17:212. [CrossRef] [PubMed]

2. Heiberg KE, Ekeland A, Bruun-Olsen V, Mengshoel AM. Recovery and prediction of physical functioning outcomes during the first year after total hip arthroplasty. Arch Phys Med Rehabil 2013; 94:1352-9. [CrossRef] [PubMed]

3. Hamilton DF, Loth $F L$, MacDonald DJ, Giesinger $K$, Patton JT, Simpson AH, et al. Treatment success following joint arthroplasty: Defining thresholds for the Oxford hip and knee scores. J Arthroplasty 2018; 33(8):2392-7. [CrossRef] [PubMed]

4. Judge A, Arden NK, Batra RN, Thomas G, Beard D, Javaid $M K$, et al. The association of patient characteristics and surgical variables on symptoms of pain and function over 5 years following primary hipreplacement surgery: a prospective cohort study. BM] Open 2013; 3:e002453. [CrossRef] [PubMed]

5. Kawai T, Kataoka M, Goto K, Kuroda Y, So K, Matsuda S. Patient- and Surgery-Related Factors that Affect Patient-Reported Outcomes after Total Hip Arthroplasty. J Clin Med 2018;7(10):358. [CrossRef] [PubMed]

6. Weel $H$, Lindeboom $R$, Kuipers SE, Vervest TMJS. Comparison between the Harris- and Oxford Hip Score to evaluate outcomes one-year after total hip arthroplasty. Acta Orthop Belg 2017;83(1):98-109. [PubMed]

7. Learmonth ID, Young $C$, Rorabeck $C$. The operation of the century: total hip replacement. Lancet 2007; 370(9597):1508-19. [CrossRef] [PubMed]

8. Arden NK, Kiran A, Judge A, Biant LC, Javaid MK, Murray DW, et al. What is a good patient reporetd outcome after total hip replacement? Osteoarthritis Cartilage 2011;19(2):155-62. [CrossRef] [PubMed]

9. Harkess JW, Crockarell JR. Arthroplasty of the hip. In: Canale TS, Beaty JH, editors. Campbell's Operative Orthopaedics. $12^{\text {th }}$ ed. Philadelphia (PA): Mosby Elsevier; 2013. p. 159-310. [CrossRef]

10. Brander V, Stulberg SD. Rehabilitation after hip- and knee-joint replacement. An experience- and evidencebased approach to care. Am J Phys Med Rehabil 2006; 85(11 Suppl):98-118. [CrossRef] [PubMed]

11. Kjærgaard N, Kjærsgaard JB, Petersen $C L$, Jensen $M U$, Laursen MB. Thresholds for the Oxford Hip Score after total hip replacement surgery: a novel approach to postoperative evaluation. J Orthop Traumatol 2017; 18(4):401-6. [CrossRef] [PubMed]

12. Judge A, Cooper C, Arden NK, Williams S, Hobbs N, Dixon D, et al. Preoperative expectation predicts 12month post-operative outcome among patients undergoing primary total hip replacement in European orthopaedic centres. Osteoarthritis Cartilage 2011; 19:659-67. [CrossRef] [PubMed]
13. Harris WH. Traumatic arthritis of the hip after dislocation and acetabular fractures: Treatment by Mold arthroplasty. An end-results study using a new method of result evaluation. J Bone Joint Surg Am 1969; 51(4):737-46. [CrossRef] [PubMed]

14. Bengtsson A, Donahue GS, Nemes S, Garellick G, Rolfson O. Consistency in patient-reported outcomes after total hip replacement. Acta Orthop 2017;88(5): 484-9. [CrossRef] [PubMed]

15. Judge A, Arden NK, Kiran A, Price A, Javaid MK, Beard $D$, et al. Interpretation of patient-reported outcomes for hip and knee replacement surgery: identification of thresholds associated with satisfaction with surgery. J Bone Joint Surg Br 2012;94:412e8. [CrossRef] [PubMed]

16. Murray DW, Fitzpatrick R, Rogers K, Pandit H, Beard $D J$, Carr AJ, et al. The use of the Oxford hip and knee scores. J Bone Joint Surg Br 2007;89(8):1010-4. [CrossRef] [PubMed]

17. Folstein MF, Folstein SE, McHugh PR. "Mini-mental state". A practical method for grading the cognitive state of patients for the clinician. J Psychiatr Res 1975; 12:189-98. [CrossRef]

18. Charlson ME, Pompei $P$, Ales $K L$, MacKenzie CR. A new method of classifying prognostic comorbidity in longitudinal studies: development and validation. J Chronic Dis 1987;40:373-83. [CrossRef] [PubMed]

19. Dawson J, Fitzpatrick R, Carr A, Murray D. Questionnaire on the perceptions of patients about total hip replacement. J Bone Joint Surg $\mathrm{Br}$ 1996; 78:185-90. [CrossRef] [PubMed]

20. American Academy of Orthopaedic Surgeons. Joint motion: method of measuring and recording. Edinburgh, London, Melbourne and New York: Churchill Livingstone 1988:12-5.

21. Kalairajah Y, Azurza K, Hulme C, Molloy S, Drabu KJ. Health outcome measures in the evaluation of total hip arthroplasties: a comparisom between the Harris hip score and the Oxford hip score. J Arthroplasty 2005;20:1037-41. [CrossRef] [PubMed]

22. Davis KE, Ritter MA, Berend ME, Meding JB. The importance of range of motion after total hip arthroplasty. Clin Orthop Relat Res 2007;465:180-4. [CrossRef] [PubMed]

23. Charbonnier C, Chagué S, Schmid J, Kolo FC, Bernardoni M, Christofilopoulos P. Analysis of hip range of motion in everyday life: a pilot study. Hip Int 2015;25(1):82-90. [CrossRef] [PubMed]

24. Bryant MJ, Kernohan WG, Nixon JR, Mollan RAB. Statistical analysis of hip scores. J Bone Joint Surg $\mathrm{Br}$ 1993;75(5):705-9. [CrossRef] [PubMed]

25. Bhave A, Mont M, Tennis S, Nickey M, Starr R, Etienne G. Functional problems and treatment solutions after total hip and knee joint arthroplasty. J Bone Joint Surg Am 2005;87(Suppl 2):9-21. [CrossRef] [PubMed]

26. Röder C, Staub LP, Eggli S, Dietrich D, Busato A, Müller. Influence of preoperative functional status on outcome after total hip arthroplasty. J Bone Joint Surg Am 2007;89(1):11-7. [CrossRef] [PubMed] 


\title{
POBOLJŠANJE FUNKCIJE KUKA TOKOM PRVIH ŠEST MESECI NAKON TOTALNE ARTROPLASTIKE: MERENO NA OSNOVU UPITNIKA ZA SAMOPROCENU FUNKCIJE I OBIMA POKRETA FLEKSIJE KUKA
}

\author{
Mirjana Kocić1,2, Marina Milenković3 , Marija Spalević1 , Aleksandra Krstović1, \\ Anita Stanković ${ }^{1}$, Dragan Zlatanović1,2
}

\footnotetext{
${ }^{1}$ Klinika za fizikalnu medicinu i rehabilitaciju, Klinički centar Niš, Srbija

${ }^{2}$ Univerzitet u Nišu, Medicinski fakultet, Niš, Srbija

${ }^{3}$ Republički fond za zdravstveno osiguranje, Niš, Serbia
}

Kontakt: Mirjana Kocić

Bulevar dr Zorana Đinđića 48, 18000 Niš, Srbija

E-mail: kocicm60@gmail.com

Cilj ove studije bila je procena funkcije kuka iz perspektive bolesnika, kao i merenje obima pokreta fleksije kuka i fleksione kontrakture preoperativno, tri meseca i šest meseci nakon totalne artroplastike kuka (TAK). Sekundarni cilj bila je analiza korelacije stepena postoperativne funkcije kuka, tri meseca i šest meseci nakon TAK, sa preoperativnom funkcijom, obimom pokreta fleksije i stepenom fleksione kontrakture kuka.

Longitudinalnom kohortnom studijom obuhvaćeno je 100 bolesnika sa uznapredovalim osteoartritisom kuka, kod kojih je urađena TAK na Ortopedskoj klinici, od maja 2015. do novembra 2016. godine. Bolesnici su procenjivani u tri vremenska perioda: postoperativno, 3 meseca i 6 meseci nakon TAK. Prvo su mereni obim pokreta fleksije i fleksiona kontraktura. Zatim su bolesnici popunjavali Oksford upitnik za samoprocenu funkcije kuka.

Rezultati su pokazali da je preoperativno funkcija kuka, iz perspektive bolesnika bila loša, kao što su loše bile i fleksija kuka i fleksiona kontraktura. Na kontrolnim pregledima 3 meseca i 6 meseci nakon TAK, postoperativno funkcija kuka i obim pokreta fleksije značajno su povećani $(r<0,001)$, a fleksiona kontraktura kuka značajno je smanjena $(r<0,001)$ u odnosu na preoperativne vrednosti. Prema vrednostima Spearmanovog koeficijenta korelacije, na kontronom pregledu 3 meseca nakon TAK utvrđene su značajne korelacije postoperativne funkcije kuka sa preoperativnom funkcijom kuka, fleksijom kuka i fleksionom kontrakturom, ali sve su korelacije nestale na kontrolnom pregledu 6 meseci nakon operacije. Studija pokazuje da preoperativno loša funkcija kuka i fleksija kuka mogu usporiti postoperativni funkcionalni oporavak, ali ne ugrožavaju ishod 6 meseci nakon TAK.

Acta Medica Medianae 2020;59(2):20-27.

Ključne reči: totalna artroplastika kuka, funkcionalni ishod iz perspektive bolesnika, fleksija kuka, fleksiona kontraktura kuka 